\title{
Dialogue between social movement activists and a Master's Program in youth and adult education
}

\author{
Graça Dos Santos Costa $^{1} \quad$ Patricia Lessa Santos Costa ${ }^{1}$ \\ Carla Liane Nascimento Dos Santos ${ }^{1} \quad$ ～David Mallows ${ }^{2}$
}

${ }^{1}$ Departamento de Educação, Campus ISalvador, Universidade do Estado da Bahia, Salvador, Brazil

${ }^{2}$ Department of Culture Communication and Media, UCL Institute of Education, London, UK

Correspondence

Graça Dos Santos Costa, Departamento de Educação, Campus I-Salvador, Universidade do Estado da Bahia - Rua Silveira Martins, 248 - Cabula, Salvador - BA, Brazil.

Email:gracacosta@gmail.com

\begin{abstract}
This article presents the results of a qualitative study on the relationship between social movements and a Master's Program in youth and adult education in Bahia, Brazil. It pays particular attention to the importance of antiracism in and the decolonization of the program's curriculum.
\end{abstract}

\section{THE DECOLONIAL CURRICULUM TURN IN YOUTH AND ADULT EDUCATION (YAE $\left.{ }^{1}\right)$}

The curriculum has a fundamental role as a structuring element in the process of transmission, construction, deconstruction, and reconstruction of knowledge and practices. It is a space of experiences in which all voices, desires, and representations should be welcomed, and in which all subjects require/demand respect, appreciation, and recognition. In addition to official documents and policies that guide the work of educators and students, the curriculum is a space for the exchange of experiences that in turn produce changes in content, methodology, and evaluation.

Yet constructing a curriculum brings up many epistemological and practical dilemmas, and the curriculum has been, and remains, disputed territory. Arroyo (2011) notes that the ways in which the curriculum has been constructed has excluded knowledge accumulated by the plurality and diversity of protagonists in the society. "These other ways of knowing, intervening, and signifying are seen as marginal to the logic of scientific knowledge and political intervention (Arroyo, 2011, p. 43). Disputes in the territory of curricula in recent decades include those "over the right to authorship, to creativity, to the very ability to criticize that which goes against political and ethical options" (Arroyo, 2011, p. 52). These disputes are underpinned by a desire, on the one hand, to (re)integrate other forms of knowledge seen as equally valid and legitimate and, on the other, to resist changes to the status quo (Maldonado-Torres, 2007).

Central to current curricular disputes is the notion of a decolonial turn. For MaldonadoTorres (2011), the decolonial turn 
does not refer to a single theoretical school, but rather points to a family of diverse positions that share a view of coloniality as a fundamental problem in the modern (as well as postmodern and information) age, and of decolonization or decoloniality as a necessary task that remains unfinished. (p. 2)

As such, the decolonial turn denounces the structuring logics that organize and materialize the monocultural curriculum, which is seen as constitutive of the maintenance of coloniality. A curricular decolonial turn means a change of direction from one form of knowledge to multiple forms of knowledge and involves bringing to light claims for emancipation of subaltern groups and the valorization of their knowledge.

In order to configure this proposal in the daily life of schools and universities, it is necessary to demonstrate respect for the cultural rights of the popular strata of knowledge. There are three strands to this argument, as highlighted by Freire and summarized by Scocuglia (2005, p. 87): the right to know what they do not know, that is, the right to appropriate the knowledge that has been denied them, appropriated by the ruling/dominant strata of society; the right to learn more about the knowledge they have gained from their own experiences, from their daily lives; and the right to construct their own knowledge, that is, knowledge built on their own values, interests, practices, and culture.

The basis for a decolonial pedagogy requires constant political, ethical, historical, social, and epistemic dialogue, with the construction of different pedagogical processes and practices (Walsh, 2009, p. 26). Thus, constructing a decolonial curriculum implies reconfiguring the knowledge and practices of the various actors, in order to challenge the maintenance of a reality of subordination through pedagogical practices which are the result of top-down, linear, and authoritarian logic to foster submission. It means building, implementing, and evaluating curricula that promote insurgent practices to resist, (re)exist, and (re)live (Walsh, 2009).

These reflections are of great interest to the field of youth and adult education (YAE) in Brazil, a field that can be conceptualized in a narrow or a broad sense. In the former, it is a teaching modality offered by the state and enshrined in law and its primary aim is the achievement of school level qualifications. However, in a broad sense it is much more than that. YAE, in all its forms, in the countryside, or the city, focused on basic skills or professional training, on civic values or cultural exploration, is a historical product of the struggle of social movements. It is constituted and a constituent of those oppressed sectors of society that have mobilized to defend their inclusion in the educational process.

The struggle of adults to overcome educational exclusion in order to enter the world of work resulted in proposals for the education and training of young people and adults. These led to legislation, which viewed these subjects as social, cultural, and ethical beings. Hence the urgent need for curricula that allows for the inclusion of people from different backgrounds, giving them the right to be understood and respected in their diversity and complexity. YAE is involved in a continuous dispute for space, a continuous struggle to cast itself as an instrument of broader human development, capable of emancipating previously subaltern groups. In this sense, its history cannot be reduced to the struggle for the right to a second chance at school. Instead, YAE, in this broader sense, is concerned with civic society's mobilization for effective actions in the educational field with a view to social transformation. It is sustained by the mobilization of social movements engaged in counter-hegemonic efforts, which is permeated by multiple actions that mobilize broad sectors of society.

In this article, we undertake an analysis of the basis for building a decolonial curriculum drawing on the experience of the Professional Master's in the Education of Youth and Adults (the Master's Program), a post-graduate program offered by the State University of Bahia (UNEB, Portuguese acronym), and on the dialogue of social movement activists 
(both students and staff) with the Master's Program. Initially, we present a brief reflection on the decolonial tradition of UNEB and the Master's Program. Next, we reflect on the approximation between the curriculum based on colonial studies, the education of young people and adults, and social movements. Finally, we present data on the perceptions of social movement activists of Bahia, highlighting their engagement with the education of young people and adults within the logic of decoloniality.

\section{THE STATE UNIVERSITY OF BAHIA, THE MASTER'S PROGRAM IN YAE, AND THE DECOLONIAL TRADITION}

UNEB is an autonomous institution located in the state of Bahia, in the northeastern region of Brazil. Established in 1983, it has been a pioneer in democratizing access to higher education through the implementation of quotas for previously excluded groups. UNEB reaffirms its institutional, pluriversal, and transcultural identity due to the diversity of social groups it houses. This multicultural commitment, typical of public universities in Brazil, requires the adoption of institutional policies that align with the interests and demands of organized social movements. In this article, we focus on UNEB's Professional Master's in Education of Youth and Adults, giving voice to those in the student body engaged in social movements, highlighting their reflections on the need for, and the pathway to, a decolonial turn in the construction and reproduction of the curriculum.

Decoloniality of knowledge, of power, and of being, can be considered an ethicalpolitical principle (Baierle, 2018) that opposes the logic of universalization of the monolithic, modern, Western subject, constructed on Eurocentric references, informed by Cartesian rationality, and which is supposedly neutral. This perspective of coloniality came to nourish the founding oppressive myths of modern Eurocentric domination. For Freire (1970, p. 150-151), all domination implies an invasion, not only physical, visible, but sometimes camouflaged, internalized in an oppressive way throughout the process of education and socialization. Freire suggests that this reason for the oppressive structure, operationalized through alienation, must be deconstructed through emancipatory and liberating pedagogical processes. A basic condition for the success of this cultural invasion is the knowledge on the part of those invaded of their intrinsic inferiority.

The more invasion is accentuated and those invaded are alienated from the spirit of their own culture and from themselves, the more the latter want to be like the invaders: to walk like them, dressing like them, talk like them. (Freire, 1970, p. 151)

The counterpoint to this logic implies putting into practice principles of dialogical authenticity, with the valorization of an ecology of knowledge located to the south of the dominant epistemes. This requires a decolonial turn, the incorporation of different groups and their forms of knowledge, and the recognition of other "places of speech" (Ribeiro, 2017).

The colonial project must be understood, beyond colonialism, as a hegemonic system based on oppressions of all kinds. As such, decolonial/post-colonial epistemologies have emerged from a long tradition of resistance by Black and Indigenous populations. The potential of the political academic project of decoloniality lies in its ability to unveil the historical relations of the coloniality of power, being and knowledge, and to propose strategies to transform the current reality (Bernardino-Costa et al., 2019). The importance of this academic political project of decoloniality is justified considering, among others, the role historically undertaken by westernized universities in reproducing hegemonic knowledge structures that exclude the epistemologies of the South (Santos, 2014). 
Thus, for the purpose of this discussion, decoloniality is understood as an ethical, political, and academic movement, representing more than 500 years of struggle of indigenous, African and Afro-diasporic populations. It strives to "bring to the forefront the political struggle of black women, quilombolas of different black movements, the people of saints ${ }^{2}$, and young people from the peripheries" (Bernardino-Costa, et al., 2019, p. 9). For this, it is essential to create new spaces where the subalterns can speak, explain their stories of struggle, and their ways of knowing and resisting. In this perspective, it is of utmost importance to understand the dialogues of social movement activists with the university, and to identify the propositions that they reveal, in order to inspire a decolonial curricular turn in the academic sphere.

It is in this context that we now turn to the Master's Program. This professional program, created in 2013, sought to respond to the need to train professionals to work in the field of YAE, which has historically been invisible and accorded little value in Brazil. In this sense, training a YAE teacher is an act of rebellion, a form of resistance and struggle (Haddad \& Pierro, 2000). To be a teacher of YAE is to be a militant, to be committed to the historical struggles waged on behalf of the oppressed and socially subordinated.

It is these social actors in praxis who are qualified to deconstruct the cognitive empire by pointing out the paths toward the decoloniality of being, knowledge, and power. It is from the reading of their interchanges with their political and identity collectivities, as well as from their interventions in training members of this embodied territory, that the Master's Program and its innovative pedagogical practices can orient the necessary changes and proposals toward emancipatory curricular pedagogies.

The Master's Program aims to prepare teachers, and others engaged in YAE in Bahia, with scientific, didactic-pedagogical, technical, political and ethical skills in the area of YAE to work in the labor market. The Master's Program is organized under three major subject areas $^{3}$ : (1) Education, environment, and work, (2) teacher training and public policies, and (3) educational management, and information and communication technologies. As can be seen in Table 1 below, from 2013 to 2020, of the total of 238 students enrolled in the program, 77 opted for area 1, 99 for area 2, and 68 for area 3.

The respective areas of concentration structure the teaching and research interventions in the field of YAE. Teaching is carried out through a diversified curricular program with curricular components distributed across three groups. The common core is composed of the following curricular components: philosophical and historical foundations in YAE,

TA B L E 1 Enrollment in the Master's Program

\begin{tabular}{lllll}
\hline & Approved & & & \\
\cline { 2 - 5 } Year & $\begin{array}{l}\text { Area 1 Education, } \\
\text { environment, and Work }\end{array}$ & $\begin{array}{l}\text { Area 2 Teacher training } \\
\text { and public policies }\end{array}$ & $\begin{array}{l}\text { Area 3 Education } \\
\text { management and ICT }\end{array}$ & Enrollment \\
\hline 2013 & 11 & 13 & 6 & 30 \\
2014 & 9 & 14 & 7 & 27 \\
2015 & 9 & 14 & 7 & 30 \\
2016 & 10 & 12 & 10 & 30 \\
2017 & 8 & 14 & 8 & 29 \\
2018 & 9 & 12 & 10 & 31 \\
2019 & $\mathbf{1 0}$ & $\mathbf{1 0}$ & $\mathbf{1 0}$ & $\mathbf{3 0}$ \\
2020 & $\mathbf{1 1}$ & $\mathbf{1 0}$ & $\mathbf{1 0}$ & $\mathbf{3 1}$ \\
TOTAL & $\mathbf{7 7}$ & $\mathbf{9 9}$ & $\mathbf{6 8}$ & \\
\hline
\end{tabular}

Source. Secretariat of the Master's Program 2018. Prepared by the authors. 
legal foundations and public policies of YAE in Brazil, educational concepts, and curricula in education in YAE, and citizenship and ethical inclusion in YAE. The specific nucleus is composed of the following curricular components: cognitive development and acquisition of reading and writing in YAE (area 1); the training of the researcher teacher (area 2); educational management in YAE (area 3); thematic seminars (areas 1, 2, and 3); guided research (areas 1, 2, and 3); and supervised teaching practice (areas 1, 2, and 3). The Master's Program also offers an optional nucleus composed of the following components: theoretical and methodological foundations of Freire's conception of education; social movements and education in YAE; anthropological foundations of race relations in education; digital inclusion and YAE; processes for acquiring mathematics in YAE; and applied research, development, and innovation.

These nuclei inform the theoretical-practical basis for the research projects carried out by participants which are at the center of their theses. These fall under three categories: (a) Intervention projects, (b) Applied research projects, and (c) Technical and technological development projects. Intervention projects have an empirical basis, and their concept and realization should aim for the understanding or resolution of a problem. Applied research projects should be oriented to the production of knowledge, whose results can be applied for practical purposes. Technical and technological development projects focus on innovations which result in new products, processes, or services. Analysis of the subject areas of the theses of graduates of the Master's Program, during the period 2015 to 2017, highlights three major recurrent themes in the studies carried out: teacher training, school management, and the subjects of YAE (Dantas, 2019). Another study highlights the impact of the activities of the Master's Program's graduates in a wide range of educational settings, with a focus on pedagogical, administrative, financial, political, and technological issues relevant to YAE (Lopes, 2019). From a decolonial perspective, it can be said that the research promoted within the scope of the Master's Program allows for the unveiling and denunciation of the reality imposed on the subjects of YAE, as well as for the proposals for solutions and alternatives (Dos Santos Costa et al., 2020).

The Master's Program is also active in outreach to the community, with interventions carried out by the respective subject areas, such as seminars, sample classes, international research meetings, and scientific cafes. This work has enabled the creation of internal and external networks for the production and dissemination of knowledge produced by the students, graduates, and staff of the Master's Program, providing a privileged locus of presentation and dialogue of innovative practices. We can draw on the concept of "circularity of knowledge" (Sordi \& Ludke, 2009, p. 332) to emphasize the importance of such initiatives in decolonization. The circularity of knowledge emphasizes the need not to "transfer knowledge from top to bottom, but to circulate between two (or more) sources that produce knowledge, each enriching, in its own way, the construction of knowledge about you" (p. 333). If knowledge is shared horizontally, in networks involving the community and the university, all participants become legitimate and valued members of a culture that promotes meaningful learning. Promoting the circularity of knowledge and engaging members of social movements is of particular importance within the Master's Program, as so many of the subjects of YAE already arrive as members of these social movementsthe Black movement, the Indigenous movement, the quilombola movement, the Landless movement, the homeless Movement, the Feminist movement.

\section{YAE AND SOCIAL MOVEMENTS}

The social movements work to raise awareness and effect change related to race, gender, ethnicity, and other social issues. For Santos (2005), these can be termed new movements 
because they highlight new forms of oppression that go beyond those related to the concept of class. Social movement activists mobilize to denounce the asymmetries, inequalities, poverty, and neglect faced by people on the margins of society. The movements in defense of YAE signal the importance of this struggle, highlighting the importance of transforming the current reality of those for whom they advocate.

The plurality of people who mobilize around collective causes has encouraged the social sciences to look beyond an analysis based solely on class. This reconfiguration has brought the actions of the so-called new and brand-new movements into focus. Their nuances, ways of acting, and demands, as well as their heterogeneous theoretical and methodological positions provide a broader lens through which to understand and address issues related to education, environment, work, gender, race, religion, among others, within a context of global economic, social, political, environmental, and technological changes.

Ruth Cardoso (1994) points to a period in Brazil between the 70s and 80s in which the social movements focused on popular and labor demands, driven by the struggle against an authoritarian and clientelist society. This was a period of reorganization of the struggle, including the revitalization of the unions, the reconstitution and formation of NGOs and other social movements. The 1990s and 2000s, on the other hand, are seen by Brazilian scholars as a period of expansion of demands, many of which were formalized in the democratic constitution of 1988. In this period, the social movements are also seen to have become more focused and organized. With the restoration of democracy, the relationship between civil society and public power also changed, becoming more ambiguous as many social movement leaders, and the NGOs they worked through, became part of the state framework. This was a new situation for social movement activists, traditionally antagonistic to the state, or constituting fields of conflict led by actors who oppose an adversary who has control of the political and economic system (Touraine, 1977).

Social movements in Brazil have redefined the notion of citizenship, contributing to a broader vision of democracy, of the right to have rights, a fundamental requirement for the constitution of active and participative subjects in social causes. In other words, citizenship occurs in the political field and in social practice involving civil society and the state (Dagnino, 2002).

YAE is more than a teaching modality. It involves the school community and its actors (managers, teachers, students, employees) directly participating in the educational process, but also the local community, civil society, NGOs, and social movements, particularly those that defend the right to education for that significant sector of the Brazilian population who are mainly Afro descendants from the most impoverished sectors of society. Of course, the educational process is not restricted to teaching-learning within the school building. It takes place in many different spheres within the community.

Learning processes and new concepts emerge from processes generated in the daily life world, from the interactive and communication processes of men and women, on a daily basis, solving their problems of survival, creating a new sector of non-formal education. (Gohn, 1999, p. 23)

It is exactly these instances of collective action that allow for the articulation of formal and non-formal educational experiences. The university's engagement with the social movement activists, including graduates of the Master's Program, YAE teachers, and participants in social movements, such as the Bahian YAE Forum ${ }^{4}$, contributes to the creation of a decolonial curriculum. The Master's Program provides a space for the development of a counter-hegemonic perspective, and that space is occupied by the various subjects of YAE. When carrying out applied research on YAE, with a view to developing interventions 
to address identified problem situations, the Master's Program's students and the staff who support them contribute to the continuous strengthening of the struggle of social movements to denounce and confront oppression. Analysis of the interchanges between the Master's Program and its graduates who participate actively in social movements allows us to shed light on the potential for such connections to contribute to the construction of a decolonial curriculum for the Master's Program.

\section{METHODOLOGY}

In this study, we draw on empirical data from participants in the Master's Program in Youth and Adult Education of the UNEB. The participants are current students or graduates of the program who are also involved with the work of social movements. We explored their perceptions of YAE, highlighting the interchanges with, interventions in, and propositions for the curriculum of the Master's Program, and for the training of YAE teachers within the logic of decoloniality.

The study uses an exploratory-descriptive method, with a qualitative approach, to reconstruct the dynamics of these interchanges between members of social movements and the Master's Program. The empirical object was analyzed in depth, seeking to unveil the essence of the process in question (Lüdke \& Andre, 1986).

The study was carried out in two phases: a literature review, followed by the implementing of three focus groups. We used purposeful sampling to select the participants in the focus groups. In doing so, we sought to prioritize individuals whose testimonies would allow us to better understand the interchanges between participants and the Master's Program, the propositional focus of such engagement, and the practical actions or interventions in the curriculum of the Master's Program that ensued. Focus group participants were either graduates or current students of the Program from six separate cohorts (2014 to 2019), and all have maintained a close relationship with the Master's Program as alumni, participating in events promoted by the Program and its research groups. All are experienced teachers of YAE in the municipal network in Bahia; three of them have worked in YAE for the span of 10 and 12 years, two between 20 and 23 years, and one for over 32 years.

The three focus groups, each lasting two and a half hours, were held online in the month of February 2021. Content analysis was used to identify, organize, describe, and report on the themes found within the data set.

Of the six participants, five have direct links to social movements, and one, although not currently active, has a history of engagement with social movements. Participants are active in different social movements. The Bahian YAE Forum (FEJA, Portuguese acronym) is part of a national network created in 1999 to advocate on behalf of YAE students and teachers. The Bahian YAE Forum was formed in 2002 and has members from the municipal and state providers of YAE as well as from the State and Federal Universities in Bahia. Junina Carcarás do Sertão (June Festival Hawks of the Hinterland) (JCS, Portuguese acronym), is a social and cultural movement that brings together young people in order to preserve and affirm their cultural and social identities. Participants were also active in the Black movement in Bahia, which has its roots in resistance to slavery and its historic legacies of structural inequality, and currently brings together a plurality of agendas linked to the fight against racism. The Coletivo Policiais Antifascistas (Antifascist Police Collective) (CPA, Portuguese acronym), Coletivo Pretos no Topo (Black Collective on Top) and Movimento Negro (the Black Movement) (CPT, Portuguese acronym), all call for the demilitarization of the police. They also criticize both the criminalization of poverty 
and the extermination of Black youth by security forces and through exposure to criminal gangs.

\section{INTERCHANGE BETWEEN SOCIAL MOVEMENT ACTIVISTS AND THE MASTER'S PROGRAM IN YOUTH AND ADULT EDUCATION}

The data have been organized into three categories to reflect the subjects' involvement in YAE and in social movements, as well as their participation in the Master's Program. In our analysis, we highlight the practical actions that contributed to (re)thinking the Master's Program curriculum. We ground this analysis in the work of Santos (2007), who draws attention to the need for Brazilian public universities to build a new resistance movement in the face of the modern project of Western civilization and the advancement of neoliberal globalization, since the combination of these processes have led to the production of social injustices, disaffiliation, and allowed the state to deny its responsibility for public assets. This situation, in turn, has caused crises for public higher education institutions regarding hegemony and legitimacy. Santos suggests that the solution to such trends lies in the establishment of democratic and emancipatory reform of the university. Such reform would include the democratization of access through affirmative action policies, the construction of "alliances downwards," recognizing the role of social movements and popular education and, also, the decolonization of curricula to ensure that no one feels exiled within the university itself.

Such alliances have been built within the scope of the Master's Program. This is evident in the pathways reported by participants in which they outline their experience with social movements:

I entered the forum and then in the forum we clearly have a much more organized form of struggle, because it is a Brazil-wide movement. In fact, the Brazilian forum started in 1997, right? '97. It starts with CONFINTEA, right? that happened in Hamburg, Germany; it started in that period. The Bahian YAE Forum started in 2002, so in 1984 I was already involved in this issue of Youth and Adult Education, in the literacy of young people and adults, and when the forum began, I entered 2 years later. (FEJA)

First, speaking of Junina Carcarás do Sertão, for me, firstly, it is synonymous with respect for my ancestry, respect for my essence as a person from the country, I am from the hinterland, and I have this authenticity and I have an obligation ... So it is one of the things that we try to focus on more within this movement, it is precisely ... we need to prioritize these kids, and when I say kids, boys and girls and all of them, so that they can search for their identity and, really, show that they have talent and that they can go further and they cannot be oppressed by the society that marginalizes them; so, the first thing we try to do within our group is to have them go back to school, either at YAE or at a regular school, because they need to embrace their identity and not let anyone exclude them from anything. (JCS)

When I came to the Master's Program and began talking with my colleagues, then I started to realize that I had had a popular movement inside me for a long time, inside my veins, and besides all that, I had also participated in a group of popular movements. And that was when Junina appeared and we were given 
continuity and what I mean when I talk about Junina is that, in addition to being a process in which we inserted the LGBTQIA+ community, it is also a process in which we also stay active. (JCS)

I would say that I am a militant who, in an institution, or not, I am acting in society in the spaces I occupy today. I have as my main activism, let's say my main task as a healthy militant is related, for example, to the fact that I am a police officer; I am a civil police officer, and I am the founder of the anti-fascist police movement. (CPAF)

From the coolest point of view, I'm involved in the coordination of PRETOS NO TOPO which is a group of black people. (CPT)

The Antifascist Police Collective and Coletivo Pretos no Topo are an important part of the Black movement in Bahia, an important sphere of social movements, with an agenda of struggle aimed at the implementation of social reparation policies through affirmative action; they respond to the injustices caused by structural racism historically reproduced in the country, and by the persistence of coloniality in the distribution of power and knowledge production.

Recognizing the value of the experiences built in such spaces is essential for the practice of an ecology of knowledge, and for the elaboration of proposals to bring together "epistemologies of the South" which are characterized by the viability of "other pedagogies." Such pedagogies must be based on education, in order to transgress epistemic, cultural, and cognitive barriers, and to give value to the diverse and significant reading of the existence of these "other" subjects.

When thinking about the role of the Black movement in Brazil, Gomes (2017) defines it as an educational movement and argues that pedagogy and pedagogical practices are open to the knowledge produced, articulated, and systematized by such social actors. Gomes also suggests that thinking about the decolonization of curricula necessarily involves the recognition and appreciation of different socio-cultural practices.

This is a two-way process, in which we adopted a dialectical and dialogical perspective in which not only is the program open to such dialogue, but also the social movements themselves:

We also need to talk from our side of our commitment to the Master's Program. We, who are popular movements, social movements, we also must commit to this process. And so, when we talk about bringing people who are active in social movements to open spaces in YAE, we know that these people have practical knowledge and that they generally do not feel comfortable with the abstract knowledge that is demanded by the academy ... But, on the other hand, they need to take ownership of this in order to become a complete activist; we also need to understand the culture, the hegemonic culture as well. (FEJA)

My main school is the social struggle, given it was the social movement that led me to the university, and not the other way around. I only approached the university, I just woke up to study, to go beyond that space that I was destined to remain at, the middle level, because I talked to this environment of social struggle and that opened my horizons. So I am a person, before anything, you know, that comes from the social movement. (CPA) 
My commitment has always been an activist one; I was never organic within the social movements, but as an activist I consider myself to be a cell of these mov .... of this much larger movement, which is the struggle for citizenship, it is what we really fight for ... for the right, in fact, to life, for the right to education, for the right to criticism to understand the reality that surrounds us. (CPT)

In these quotes we see not only a commitment to the Master's Program, and to their own professional development, but also a commitment to strengthening the program, articulating their experiences within society to provide support and visibility to the only YAE program in Brazil. We also witnessed, as teachers of the Program, their involvement in the events and publications produced within the Program; and we were able to participate in events held by these social movement activists of which they are part, and in the schools in which they operate.

The people of YAE participating in social movements are part of complex social structures (school, movement) in which they establish singular, subjective relationships, and in which they act with even greater capacity to make a reinterpretation of this prescriptive and normative universe. Amid these considerations, we can say that they not only build their professional and life trajectories in these different instances, but also acquire experience to interact with others, defending their beliefs, and sharing their knowledge.

Proposals presented in the focus groups covered access and permanence of social movement activists in the university, the revision of the curriculum based on personal practical knowledge, and the production of knowledge based on racial issues. Regarding the expansion of access to the university, one of the propositions presented was the creation of reserved allocations for social movements activists: "Why not open this right to spaces for social movements, also, in addition to those that already exist for other collectives? Because then, that person would feel included and would be able to contribute to the struggle" (CPT). From the point of view of the permanence of social movement activists in the university, a committee that would support and help militants complete their program was suggested:

I have a little experience accompanying some colleagues from the Master's Program itself and I realized that in addition to the supervisor, they would need someone else to help them in the development of their theses. It is not that they didn't know, but that they needed someone to provide this greater support, and I think that Program needs to open up, because, when we talk about YAE, we may not want to use pre-established standards; we may need to create new ones. (FEJA)

Decoloniality in the context of the curriculum implies the valorization of different processes of knowledge production. The selection of knowledge in the curriculum is a very important step in the decolonial turn, and it is also a very important way to establish dialogue with the movements and their demands.

I think that what's really needed is having a curriculum, which dialogues ... with these demands, and I have already identified that to some extent; the Master's Program does this to the extent that it has disciplines such as Social Movements, you know, there is this discipline ... which is not mandatory, which is optional, which must be ... which, in my view, should become mandatory; it is thinking about strengthening this curriculum, it is decolonial by the Program, as it has a discipline of, of inclusive education, in short; and then think of other 
ways to, to become and to strengthen this, your potential to be an instrument for popular demands. I think that's it. (CPA)

We should strive to build curricula with components that enable the promotion of such popular demands; in other words, we should include those demands which reflect the struggles and the experiences of those within them. For this to succeed, other forms of knowledge should be included in both the prescribed and the practiced curriculum. In this sense, another suggestion was to include other epistemological and methodological knowledge from social movements to achieve a curricular revolution.

Building a decolonial curriculum would have to be a revolution even in education, a revolution. Because we know that the colonial curriculum is still predominant, because we view true knowledge as modern; it is knowledge that is characterized a lot by abstraction; we do not value practical knowledge, ... what predominates is abstract knowledge. (FEJA)

People do not understand and have no interest in listening to abstract speech. They listen to the people talking about practical knowledge because it speaks of what they are; it speaks of their place. So, the way I talk is very practical, and, when I write, this practicality also shows. (FEJA)

Despite highlighting the need for dialogue with practical knowledge drawn from different ways of being, with life in the center,

it is not a matter of recognizing, tolerating, or incorporating the different within the established matrix and structure; on the contrary, it is a question of boosting, (re) contextualizing and (re) founding social, epistemic and existence structures that put different logical, practical and cultural modes into play and in equitable relationships. (Walsh, 2014, p. 4)

For this reason, dialogue should not exclude, but instead seek equity between different forms and sources of knowledge. As the participant below points out, militants need to apprehend and master hegemonic knowledge.

We know that these people have practical knowledge and that they generally do not feel at ease with the abstract knowledge that is demanded by the academy, but that, on the other hand, they need to appropriate it to become a complete militant. We also need to understand the culture, the culture of hegemony as well. I don't use it because I don't think it's necessary to use it, but if I have to, I do. (FEJA)

In addition to curricular reformulation, an important element highlighted by one participant is the contextualization of knowledge and the need to learn from the experiences and knowledge of our Latin American brothers and sisters, from their critical pedagogies in particular:

Proximity to the Latin American brothers who made us independent with fight and blood and therefore have a more decolonial tradition. It is a way in which they build new people with other ways of thinking and doing and through other pedagogies. (FEJA) 
It seems so obvious, but often the obvious does not reach the curriculum.

Although we are Latin Americans, and we have our own way of doing things, we have our pedagogies originating from indigenous peoples, but they are considered something lesser, theirs does not seem real to us, the "real" is the model that comes from Northern Europe and North American. (FEJA)

In this same direction, a proposal for an important curricular turn is the collaborative construction of knowledge from different voices, from a horizontal perspective in teaching and research:

The graduates who are linked to social movements could return as collaborators to help the Master's Program with this or that student who does not have the ability to write a thesis. They have abilities, but not that one. How many students are there in this mental health process where they just need a push to be able to move forward? If we are thinking about the future, I think that would be a proposal. (CPT)

In addition to the construction of collaborative knowledge by several actors, another proposal concerns the production of knowledge from an Afrocentric perspective. It was highlighted that the theses produced through the program do not engage sufficiently with racial issues; even though the university has made progress in affirmative policies, inclusion does not translate into academic production.

There are quotas, but this quota is not necessarily reflected in academic work on the racial debate; that is, including Blacks has not resulted in bringing more work on race relations into the master's degree and I also identify that this may have a relationship with the fact that the master's degree itself does not have this debate at its core, it does not have a mandatory discipline. ...so, the debate on social relations is embedded there as a subtitle, but it does not bring in its centrality. The only discipline is optional, which is the discipline of anthropological foundations. (CPA)

From this perspective, the curricular turn is constructed by denouncing all forms of discrimination and questioning the absence of other knowledges and of dialogue with social movements. What is the knowledge that social movements produce that should be the basis for a decolonial curriculum?

\section{FINAL CONSIDERATIONS}

The curricular turn from the decolonial perspective, based on the perceptions of social movement activists, can be characterized as a true epistemological and methodological revolution. As one participant pointed out, the university is often seen as an ivory tower, distant from the realities of everyday life, and it needs to leave its comfort zone, reach out to the social movements, and bring their demands into the curriculum. Doing so would mean valuing different types of knowledge equally, opening oneself to listening to other voicesthose from practice, and from the fight for human rights. It is not just a matter of opening doors for access or creating specific administrative policies for the inclusion of different groups, but, above all, reviewing the type of knowledge produced by the university, the 
forms of socialization of that knowledge, and the dialogues that take place between it and other forms of knowledge.

In addition to the institutional policies, the social movement activists find in the Master's Program an epistemological and methodological shelter for the identification of their struggles for human rights. According to one participant, the program disciplines and the focus of the research carried out within the program already bring knowledge that is aligned with the demands of social movements. As such, the Program is an instrument at the service of social struggle and popular demands.

The Master's Program already has, by its very nature, you know, YAE is a social demand, YAE, it brings a demand for social struggle, so I think that is why there is no way of separating it from the struggle of social movements. (CPA)

For this reason, exploring the perceptions of the education of the activists in Bahian social movements, highlighting dialogues within the education of young people and adults, within the logic of decoloniality, provides a powerful way for us to think about the curricular turn. Examination of participants' life histories, and interrogation of the lack of knowledge of social movements in the curriculum, provides clues for the construction of a curriculum within the decolonial perspective. It remains now to move beyond minor decolonial interventions and take advantage of these clues to carry out a true curricular turn in the education of young people and adults in Bahia.

\section{NOTES}

${ }^{1}$ In Brazil adult education is referred to as education for youth and adults (Educação de Jovens e Adultos) and is known by the Portuguese acronym EJA. The editors have translated it to Youth and Adult Education (YAE).

2 The people of saints ("Povo de Santo" in Portuguese) refers to the followers of Candomble an African diasporic religion that developed in Brazil during the 19th century.

3 According to CAPES (Coordination for the Improvement of Higher Education Personnel), the Brazilian Government agency responsible for postgraduate study, subject area refers to the initial and/or historical vocation of the Program and must indicate the area of knowledge to which the program belongs, the general outlines of its specialty, knowledge production, and expected training.

4 The Bahian YAE Forum (Forum EJA Bahia) is an advocacy group formed by teachers and others which argues for increased visibility and funding for YAE. http:// forumeja.org.br/ba/

\section{R E F E R E N C E S}

Arroyo, M. G. (2011). Currículo, território em disputa [Curriculum: Territory in dispute]. Editora Vozes.

Baierle, S. G. (2018). The explosion of experience: The emergence of a new ethical-political principle in popular movements in Porto Alegre, Brazil. In S. E. Alvarez, E. Dagnino, \& A. Escobar (Eds.), Cultures of politics: Politics of cultures (pp. 118-140). Routledge.

Bernardino-Costa, J., Maldonado-Torre, N., \& Grosfogel, R. (2019). Decolonialidade e pensamento afrodiaspórico [Decoloniality and aphrodiasporic thinking.]. In J. Bernardino-Costa, N. Maldonado-Torres, \& R. Grosfogel (Eds.), Decolonialidade e pensamento afrodiaspórico [Decoloniality and Afro-diasporic thought] (pp. 9-26). Auténtica Editora.

Cardoso, R. C. L. (1994). A trajetória dos movimentos sociais [The trajectory of social movements]. In E. Dagnino (Ed.), Os Anos 90: Política e Sociedade no Brasil [The 90s: Politics and society in Brazil] (pp. 81-90). Brasiliense.

Dantas, T. R. (2019). A formação de professores em educação de jovens e adultos (eja) na perspectiva da inclusão social [The training of teachers in adult and youth education from the perspective of social inclusion.]. Revista de Educação, Ciência e Cultura Canoas, 24(1), 29-39. https://revistas.unilasalle.edu.br/index.php/Educacao/ article/view/4570/pdf

Dagnino, E. (Ed.). (2002). Sociedade civil e espaços públicos no Brasil [Civil society and public spaces in Brazil]. Paz e Terra.

Dos Santos Costa, G., Mallows, D., \& Santos Costa, P. L. (2020). Paulo Freire, the decolonial curriculum and the experience of the Professional Masters in Youth and Adult Education in Bahia, Brazil. Adult Learner: The Irish Journal of Adult and Community Education, 2020, 96-110.

Freire, P. (1970). Pedagogy of the oppressed (M. Bergman Ramos, Trans.). Herder \& Herder. 
Gomes, N. L. (2017). O movimento Negro educador [The Black Movement educator]. Vozes.

Gohn, M. G. (1999). Movimentos sociais e educação [Social movements and education]. Cortez.

Haddad, F., \& Di Pierro, M. (2000). Escolarização de jovens e adultos [Schooling of youth and adults]. Revista Brasileira de Educação, 14, 108-130.

Lopes, N. (2019). Gestão dos egressos em universidades públicas: Uma proposta de acompanhamento e de relacionamento do egress do Mestrado Profissional em Educação de Jovens e Adultos [Management of alumni in public universities: A proposal for monitoring and relating the alumni of the Professional Master's in education for youth and adults. [Unpublished doctoral dissertation]. Universidade do Estado da Bahia, Brazil.

Lüdke, M., \& Andre, M. (1986). Pesquisa em educação: Abordagens qualitativas [Education research: Qualitative approaches]. EPU.

Maldonado-Torres, N. (2007). On the coloniality of being: Contributions to the development of a concept. Cultural Studies, 21(2/3), 240-270.

Maldonado-Torres, N. (2011). Thinking through the decolonial turn: Post-continental interventions in theory, philosophy, and critique-An introduction. Transmodernity, 1(2), 1-15.

Ribeiro, D., (2017). O que é lugar de fala? [What is a place of speech?]. Letramento.

Santos, B. S., (2005). Os novos movimentos sociais [The new social movements]. In R. Leher \& M. Setúbal (Eds.), Pensamento crítico e movimentos sociais: Diálogos para uma nova práxis [Critical thinking and social movements: Dialogues for a new praxis]. Cortez.

Santos, B. S. (2007). Cognitive justice in a global world: Prudent knowledges for a decent life. Lexington Books.

Santos, B. S. (2014). Epistemologies of the South: Justice against epistemicide. Routledge.

Scocuglia, A. C. (2005). As reflexões curriculares de Paulo Freire [Curricular reflections of Paulo Freire]. Revista Lusófona de Educação, 6, 81-92.

Sordi, M. R. L., \& Ludke, M. (2009). Da avaliação da aprendizagem à avaliação institucional: Aprendizagens necessárias [From learning assessment to institutional assessment: Necessary learning]. Avaliação: Revista da Avaliação da Educação Superior, 14(2), 313-336. https:// doi.org/10.1590/S1414-40772009000200005

Touraine, A. (1977). Os movimentos sociais [The social movements]. In M. M. Foracchi \& J. de S. Martins (Eds.), Sociologia e sociedade [Sociology and society]. LTC.

Walsh, C. (2009). Interculturalidade crítica e pedagogia decolonial: In-surgir, re-existir e re-viver [Interculturality, criticism and decolonial pedagogy: To rise, re-exist and re-live]. In V. M. Candau (Ed.), Educação intercultural na América Latina: Entre concepções, tensões e propostas [Intercultural education in Latin America: Between conceptions, tensions, and proposals] (pp. 12-42). 7Letras.

Walsh, C. (2014). Pedagogias decoloniais caminhando e perguntando. Notas para Paulo Freire de Abya Yala [Decolonial pedagogies walking and asking. Notes for Paulo Freire from Abya Yala.]. Revista Entramados - Educação e Sociedade, 1(1), 17-31.

\section{AUTHOR B I O G RAPHIES}

Graça Dos Santos Costa is a professor in the Department of Education at the State University of Bahia (UNEB), Brazil.

Patricia Lessa Santos Costa is a professor in the Department of Education at the State University of Bahia (UNEB), Brazil.

Carla Liane Nascimento Dos Santos is a professor in the Department of Education at the State University of Bahia (UNEB), Brazil.

David Mallows is an associate professor in the Institute of Education at University College London. 
How to cite this article: Costa, G. D. S., Costa, P. L. S., Santos, C. L. N. D., \& Mallows, D. (2021). Dialogue between social movement activists and a Master's Program in youth and adult education. New Directions for Adult and Continuing Education, 2021, 27-41. https:// doi.org/10.1002/ace.20438 